DOI http://dx.doi.org/10.18524/2312-6809.2018.26.129463

УДК 821.161.2-4Забужко.07:81’42:162

\title{
MENTATIVE AND NARRATIVE FEATURES OF O. ZABUZHKO'S ESSAYS
}

Tetiana Shevchenko, candidate of philological sciences, doctorate candidate

Odesa I. I. Mechnikov National University, Ukraine shtn75@ukr.net

In the article mentative and narration features of $O$. Zabuzhko's essays based on the example of the book «From the map of books and people» are analysed. Essay classification in works of modern Ukrainian writers in terms of narrative and mentative nature are determined. The conclusions are made about the role of narrative components in essay discursive practices, whose nature is mentative. Special features of a writer's essay itself are outlined, since it becomes a platform for possible «prolongation» of artists' fictional works, space for their pre-interpretation and re-interpretation.

Key words: mentative, narration, essays, classification, reference.

The relevance of doing research on essays of modern Ukrainian writers is determined, first of all, by impressive productivity of such discursive practice in modern literature; secondly, by their diversity, variety, openness to artistic and communicative researches, experiments that are based on convergence, eclectics, usage of rhizome; and thirdly, by the lack of findings on their structural, communicative and pragmatic characteristics etc.

Mentative nature of an essay has just started to become comprehended in native literary criticism. It consists of statements with mental reference - mentatives. V. Tyupa characterizes mentatives as «double-acting statements» next to narrative statements. A. Korchynskiy is confident that «referent event in the narration takes place in space and time», while «mentative event - is a mental event (or rather an intellectual one), event of the though itself, arrival or birth of thought» [5]. «Mentative referent - is not just a group of concepts, principles or regularities formulated in statements that show certain concepts the way they are. It is the thought process as an act of determining the sense of certain phenomenon, creation of previously non-existent connections between two things, appearance of a new mental artefact. It is a discovery, change of coordinates in intellectual perception of the world»[9, 37-38].

Essay's discursive practice consists of mental reference as a response to the process of thinking itself, expressed verbally. Essay outlines the authors perception of the world, by using paradoxes, thoughts, deductions. Not 
events that are being told about are important but the process of narration itself, which provokes discourse - the most valuable part of the text, while referential eventfulness is connected not with the external context of essay's appearance, but rather with the communicative actualization of events, which is structurally ingrained in essay's statements. The reader, while becoming a part of these events and discourse, feels the effect of thought-birth with his/her own eyes, comprehends its «lively» nature and develops it.

Quintessence of narration in essay is different from usual one in traditional epic genres of the term «narration», «story-telling». Here the emphasis is made not on the event itself, but on the «story» that took place before the textual presentation. For example, S. Zenkin writes about conditional and imaginary ordering of these events, because it appears thanks to narration. This process is implicit, imperceptible, and therefore narrative becomes rather convenient for the broadcast of the implicit interventions of the narrator in the course of history, certain vicissitudes (for example, rearrangement of episodes, denouement or starting point). «It may have no actual events just the pure structure of actors that are able to give birth to the events» [4].

However, by determining the dominant role of mentative as the action of thought in essay's discursive practices, we can neither fully cross out facts and events that happen in reality because they become the subject of comprehension, nor a certain causal chain between them. Narration about events can often become basement for mentative's formation, as well as a vector for thought formation. Essay fragments that have narration features, are aimed at presentation of information in its development. On the one hand, they prepare the reader for perception of the thoughts named before; outline the space for one's own opinions, represented through the narrator. On the other hand, they show the result of contemplation process (in such cases narrator usually mainly serves as a participant, and only then as a referent). Of course, narrative components in essays are secondary, additional, however, they are the ones that serve as a basis for mentative, orientate the reader in the necessary direction of procedural comprehension of being.

Therefore, based on the features of mental events' structure in essays, as well as original features of reality narration that form an essay, functions of narration components in texts, interaction of mentative and narrational components etc, we conditionally divided modern Ukrainian essays, represented in collections, into three groups:

1) narrative essays, in which thoughts are primarily formed based on real events (and only rarely on imaginary ones) in time and space, that the 
narrator had lived through personally or the ones in which he had been involved, are represented in the text. In such works of literature events are chosen specifically and have their own plot, while the sequence of episodes and topics has a principled nature. Narration provokes certain thoughts that are directly connected with what had been told before. Essay's narrative block prepares the reader for mental reflexions that are not usually deployed, detailed, but are concentrated and condensed instead. Narrative component in such essays lets the author stupefy the reader and makes the thoughts more objective, while on the other hand it makes the reader comprehend the story as a precedent event and activates their thinking process. Narration that has its own unusual exposition, starting point, climax and denouement makes this process easier. Despite the importance of narrative component, its significance is secondary: it is only a basis for thought formation, a place where discourse about an event is turned into self-reflexion, into the thought itself. Therefore, «entrance» into the author's perception of the world with the help of reflexion is done step by step, slowly, while reader prepares for further brain-load by reading about the «stories» first and only then making the observations. These are the essays that had been previously published in periodicals, blogs, and only then they become a part of a compilation (M. Ryabchuk's «Previous life», S. Pyrkalo's «Egoist's kitchen», V. Zhezheras's «Postponed summer»). We are convinced that essays in the form of diaries and letters could also be added to this group, because they are abundant with events and facts that are the result of personal and social engagement and axiologization. Facts and reality phenomenon in such works acquire auto-communicable features, as they become narrator's object of comprehension while being addressed to himself/herself, and only then to the reader. Otherwise, there would have been no point in being published (V. Neborak's «Introduction to Bu-Ba-Bu», G. Pahutyak's «Previous, different...», «Each day is different», V. Mahno's «The bag was rolling down»);

2) mentative and narrative essay, in which a certain life event (narration basis) is unimportant but still relevant in reflexion formation, while mentative is the main discourse mode of represented thinking. Certain events that had been told by an author are not separated from the thinking process but are an organic addition to thoughts and intellectual coordinates, which determine the changing picture of the world, shown in essays. In such texts, the discursive timeliness of event deployment and the sparse plot only intone the flow of thoughts. The experience of reasoning as such is experienced through isolated examples of history, history-memories, events-rev- 
elations, facts-enlightenments. At the same time, they are only indirectly preparing a reference of the mental event - it is provoked by a chain of conclusions, actualization of communicative event, semantically embedded in the statements. The readability of these texts directly depends on the curiosity of the story, described in the beginning, and only then on the proposed mental practices. From our point of view, essay compilations that fit this description are the following: Y. Andruhovych's «Disorientation on the ground», «Phantomas is buried here», «The Devil hides in cheese», «Lexicon of intimate cities» etc.; O. Zabuzhko's «Reportage from 2000», «From the map of books and people», «And so I get into the tank again»; S. Protsyuk's «Shadows appear on the dawn», «Triangle» (chapter «Essays»), «Blood analysis», «Cable carriers»; I. Luchuk's «Doubts of a man in his 40-s», «Literature Jazz»; O. Boychenko’s «More / Less», «50 percent of a radio transmitter», «Just to make a book»; I. Tsyperdyuk's «Travel though fog»; I. Andrusyak's «Oaks and lions». Most essays in modern Ukrainian literature belong to this type;

3) mentative essays as they are: action is downsized to the minimum. These are the works in which «mentative narration in the text or a fragment (in essay's case - of the whole text. - Specification is mine. - T. S.) is organised by means of cognitive, suggestive, irrational or psychological thinking and is formed with the use of reflexion, as a type of thinking» [1, 22]. Reflexion turns out to be the basis for such essays: by accumulating thoughts, the flow of author's conscience acquires a certain structure, a shell, rational stability. Form of such texts «appears to be the space of reflection, formation of content and its attitude to itself, as the thinking process becomes a new creation» [7]. Consequently, the works clearly demonstrate the transition from chaos to concretely substantive consideration of consciousness, to self-observation, to critical introspection and critical self-evaluation. And all this process in a peculiar way occurs in front of the reader, who joins the processes of thought-birth and feels its involvement. This is a peculiar «inclusion» of the reader (observer) into the system (structure) of the work (M. Bahtin). Therefore, dialogism is a constitutional principle for mentative. It is a dialogic nature of a particular style and is inherent in mentative texts on the same level with their internal textual organization. Such dialogism consists of collisions within the expanded mental expression of different points of view, evaluative positions [see. 6]. As a result, it is pointless to expect visual dynamism from essays: movement of thought is not a movement of events. Monotony, deceleration, retardation are obvious features of 
such texts. Their events are distilled to the maximum and get woven into the canvas of judgments and opinions, while generating new meanings and their shades. Their role is secondary: with the help of associative ties, events in reflexive texts generate new vectors of thought deployment, while affecting the internal state and changes of the narration's subject, and resulting into mental changes of the essayist inner self. To such essays we can attribute philosophical works of K. Moskalets (collections «The game lasts», «Man on the ice», «Splashes»), G. Pahutyak («Cruelty of existence», «Drowned in the snow»), A. Bondar's «And to the ones in the tombs», T. Prohaska's «One and the same», A. Karpyuk's «Still summer, but everything is clear», V. Gabor's «What does a person think about?», Izdryk's «Flash-drive 2G» etc. Separately in this group it is necessary to name zuihitsu as a kind of essay, which has a special, philosophically unbiased view of the world, thoughts and observations, set forth in poetic language, which seems to be bursting out of the author's consciousness, and the author himself does not make any resistance to this process. He, on the contrary, enjoys this process.

According to our classification, O. Zabuzhko's collection of works «From the map of books and people» belongs to the second type. This book includes essays written during 1999-2012 and published in other resources, as well as separate texts that had not been printed before. The writer shows her «cultural map» and proposes a reader to create their own map. In order to make this process easier, she structures the book by dividing it into four parts «To read», «To write», «To see», «To live». Each part of the book presents specific cultural aspects that become a subject of analysis: personalities, texts and works of art. B. Nosova, while analysing metaphor as a way of describing intellectual's cultural space in this book, pointed out that «events, artefacts, images of people that O. Zabuzhko writes about, are protected by her talent from disappearing in eternity» [8, 144].

Whatever the author writes about - about her correspondence with V. Shereh, about her speeches on symposium in Switzerland, where she was representing modern Ukrainian writers, about A. Tarkovskiy's and O. Dovzhenko's films, about K. Bilokur's paintings, - she always begins by highlighting the importance of this person, their works, their social phenomenon for herself, retells stories, events, fats about them and herself, arranged in short plots, describes how she «opened» those personalities from the past and from the present. All of it becomes a platform for further thought process. Therefore, narrative elements in her essays have causal logics. One could determine a starting point, development of plot, climax 
and denouement, all these elements are clearly determined in time and space. Epilogue or denouement usually finish the work by showing up in the last pages, however, the main part of the text - mentative part, «opening», studying, comprehension of a certain person from past or present times serve as arrangement, become an organisational method of forming meditative texts. Before describing the feeling of anxiety and comprehension of Chornobyl tragedy, post-Chornobyl art, authorial interpretation of Lars von Trier's film «Melancholy» about that tragedy and comparison with A. Tarkovskiy's «Mirror» and O. Dovzhenko's works and films, there is a story that had happened with narrator on the 26th of April in 1986 in Kyiv, when it was raining with blue snow. Narrator describes events that happened on that day in detail, adds first impressions about them, describes her actions and «explains» reasons for turning to films about Chornobyl and Ukrainian cinematograph in general in the essay «Planet of Sagebrush: Dovzhenko - Tarkovskiy - von Trier, or Discourse on New Horror». The essay is finished again with the story from author's personal life about a distant guest in her family that told about accident's liquidation and his uneasy fight for life and health afterwards. This story gets taken into account as pointe of the essay: life carries on despite all environmental catastrophes: «Nature has everything», - his voice starts to sound like unshakable, metal solidity. «Everything that human needs. However, we do not know anything. We just forgot how to live» $[2,238]$. The main part of the text is mentative: it is space for reflection, content formation and its heading towards oneself, as a meditation process that becomes a work of art. Here we can see the demonstration of transitions from chaos to specific and objective self-analysis and critical self-evaluation (Chornobyl art - cinematograph - Lars von Trier - film «Melancholy» - works of A. Tarkovskiy - works of O. Dovzhenko - role of art in problematic sides of existence - transiency and prominence of human life - art as a way of salvation etc.). By doing that narrator turns to the past in order to change something in the future, however, interference and reflections that cause that are the reason why she tries to change something. Therefore, events happen twice: in the past, as a connotation, and now, as a reflection. Of course, reflexive component is the main one here.

A similar principle of narrative and mentative organization is also present in the essay «The topic with variations: on two teleds, with three interludes and epilogue» about freedom as a multidimensional concept. Here narrative components are even visually separated from the main text, mentative 
in nature, in the form of «first plot» and «second plot». The first one tells about events during the period of «developed socialism» (late 1970's), when the storyteller made a certain «discovery» about the Soviet Union's agility after listening to the report on how worker of an average factory works on the same machines for 19 years in row. The second one is about Y. Makarov and the beginning of the Second World War, which gives rise to thoughts about freedom of choice among Ukrainians in those circumstances. These life stories, woven into a text cloth, are clearly written, and because of being based on time and space, are linearly stated. They are needed by the author in order to start thinking in a more philosophical and culturally-historical way. The main communicative strategies of deploying mentative in this case are commenting, evaluation and development. Thus, the latter, according to N. Maksimova, «expresses the convergent mode of consciousness and is characterized by the decision to coordinate different points of view, the search for synthesis, the ways of crossing the semantic positions, decision to reach harmonious inter-subjective interaction, where «personal / foreign» relationships are influenced by the development of objective meaning» [7]. O. Zabuzhko's mentative is oriented at the mode of consciousness, which is rooted in her beliefs, while relying on the position of close people, respected philosophers, writers, historians, whose opinion keeps being valuable over time for her, if not even more important with experience, but she does not take their persuasion for granted, but rather as a reference point, and keeps developing their position, complementing and rethinking it. Such respectable figures, for example, in this work are Lesya Ukrainka with her poem «Cassandra» and the figure of Helen, who «survives» thanks to the underestimated threshold of values, G. Tyutyunnyk and his story «My Sabbath Day», M. Bahtin, O. Honchar, K. Marx, O. Pushkin, O. Tolstaya etc. O. Zabuzhko's commenting as a basis for mentative, however, should not be identified as definition. If definition is a holistic logical and communicative structure, then commentary is any lexical component of someone's statement, indifferent to the place in thesis structure, to the communicative core or the periphery of the statement. In O. Zabuzhko's essays, commenting becomes a basic communicative strategy, while definition is auxiliary: the author builds his mind, first of all, based on views and opinions of others - O. Olzhich, L. Plyushch, P. Tychyna, V. Shevelev etc., and then complements them with his or her own reflections. The author interprets their works, life positions, concepts, for example, by writing about the «instrumentality» of V. Shevelev's figure or «vivisection» of P. Tychyna's poetry. 
However, commenting is not the only communicative strategy of narrator's mentative competence that shows up in the book «From the map of books and people». She often resorts to the strategy of denial, in which the development of thought is an open discussion, an open polemic with someone or something. Consequently, essays turn into bold attempts to protest the obvious things, a vivid demonstration of fearlessness, established positions and views. Text analysis in «From the map of books and people» proves that paradox occurs when the content of thinking is expressed in a specified form and is raised to the level of abstract individuality - the ability to think. For example, in the essay about O. Oles, his phenomenon is explained by available methods and methodologies, and conclusion is made about their weaknesses and imperfections ( $«$ The Secret of Popularity») or in the essay about Y. Pokalchuk, in which an attempt was made to create the image of writer as a holistic artist in the context of his era, but the idea of integrity is destroyed all the time by the paradox of the writer himself, as well as the mythological form of his presentation, chosen by the author, multiplied by non-rational components of being. Consequently, the linear comprehension of the prose writer's personality becomes impossible, but it is compensated by the paradox of thought violation of the individuality degree, breakthrough of universality with the preservation of objectivity of the comprehended object: «To be the same age with three generations is a phenomenon itself. And this phenomenon needs to be explained. To simply say «a gift» is not enough, because one has to know how to use a gift, and in the memory of culture there are only those left, who used it properly. Therefore, again and again they turn to their experience - because of eternal temptation to understand «how they succeeded»»[2, 311].

An important feature of narrative and mentative organisation of O. Zabuzhko's texts is the interweaving of characters from her other works, plot fragments from them, quotations and allusions into her own essays. They are perceived by the author as a platform for possible «prolongation» of her own artistic works, arena for their additional interpretation or re-interpretation. Characters of her works are images-guides in the process of reflection. Through the analysis of texts, the author sometimes manages to find out certain contexts and inferences. In some cases, essay turns into an auto-review, when the writer is not satisfied with the critical opinions about her works, because they are far from decoding the author's plan. This happened with her «Fairy-tale about an arrow-wood penny-trumpet», which, 
according to the author, was not understood by critics and, in essence, distorted the meaning: «It became irrevocably clear: it would have been better to write about the Blue Beard: then I could have counted on much more understanding»[2, 113].

In essays a lot is told about novels «The Museum of abandoned secrets» and «Field studies into Ukrainian sex», the story «Fairy-tale about an arrow-wood penny-trumpet», collection of poetry «Hitchhiking». A novel about Ukrainian Insurgent Army is a certain leader in this sense: from the essays it is possible to build a peculiar history of their writing, since a lot of work had been done in archives, there have been meetings with philosophers and historians, formation of the personosphere in various senses and contexts, woven into the fabric of essayistic thinking about events of the past and the present. For example, the essay «Return to Graz» is dedicated to the writer's grandfather and his dreams about studying medicine in Graz, which were not destined to happen. The fable basis of the work is the arrival of the storyteller to that city as a tribute to the relative. This circumstance becomes the basis of the mentative reflection about bonds between generations and the circumstances of writing a large epic work «on three generations of one family, whose fates are interconnected by longitudinal, unseen consequences of choices made before, within the limits of one human's life» [2, 128]. Character prototypes of her novel became her grandfather's peers. About the novel «The museum of abandoned secrets» a lot is mentioned in the essay «Berlin: introduction to anaesthesiology» and in the "Ashes of Klaas», written in 2008 and specially refined in 2012, with the insertion about the circumstances of writing the novel and the image of Albert Gasenbrooks-«Western». Such inclusions of fragments about her own artistic works (images, allusions, overlapping, prototypes, critical reviews, reader's reception etc.) distinguish writers' essays amongst other types of them in contemporary culture: characters of artistic works continue to «live» on the pages of essays of the same authors, hence an essay becomes a «continuation» (in the metaphorical sense) of novels, stories, lyrical works of artists, while gaining new opportunities for thinking and interpretation. The creative competence of the author's mentative thus covers the meta-literary context, while assimilating artistic-shaped material through the prism of double optics: both literary and essayistic (in most cases it is a literary-critical essay, a philosophical or mixed variant). These circumstances explain changes in the functioning of narrator in essays: the primary narrator (the one who tells) turns into a hero of his own work (about whom the story is told). The primary narrator is the one that under- 
stands being as a philosophical concept. The secondary narrator is retelling the plot, fable or other vicissitudes of artistic works. In some cases, there may also be a tertiary narrator - a literary critic, a recipient. Everything that is told by the secondary narrator becomes a part of speech of the original narrator in the essay. The inclusiveness of what is said by the secondary narrator is actualized in different ways: stylistic approach to speech, commentary delimitation, most often the use of narration as a reference point for mental generalizations. According to our observations, such feature is a persistent property of writers' essays as such. For example, characters of their own works, as well as the stories about them, can often be found in the essays by Y. Andruhovych (Stah Perfetsky, Otto von F.), sometimes there are unique personal characters, works in general, images and characters as objects of observation in the essays by I. Andrusyak, Izdryk, T. Prohasko, S. Protsyuk and others like that.

Therefore, the analysis of the ways of organizing essays (mentative and narrative blocks) in the collection of works brings us to the outline of narrator's type in the book «From the map of books and people». From its pages a storyteller / a thinker appears to be extremely close to the author, but not identical with her: in most cases, narration is done from the first person, reality is reflected by the events from the writer's own life, those in which she participated personally or knows from reliable sources (for example, acquaintance with Y. Sherekh, a story about grandfather I. Zabubko, story about talking with L. Plyushch etc.). In some cases, this type of narrative approaches the narrator: he is endowed with features of the author, but tends to acquire characteristics of the female charachter from the plot (for example, in essays «The theme with variations», «Ashes of Klaas» or «About love»). In others, he is endowed with features of the narrator: he is closer to the author's consciousness, but does not completely coincide with it, openly organizes the text with his presence: «Return to Graz», «Berlin: Introduction to anaesthesiology», «The Effect of presence». However, in most cases these types are superimposed, so the notion of a narrator rather than story-teller is more appropriate in this situation. What needs to be specified is that narrator in the essay, as can be judged from the analysis of the collection, is different from narrator of an epic text: he turns into the thinker right in front of the reader, and stories that are being retold, only prepare the ground for thought-creation. V. Schmid has the point by considering the term «narrator» to be «functional», it means that he «carries out functions of narrative without any reference to certain typological features», 
he is indifferent to the concepts of «objectivity / subjectivity», «neutrality / marking» etc. $[2,38]$.

By the classification of this German philologist, we will identify other types of narrator in the book «From the maps of books and people». In our opinion, to a greater extent this is an explicit type (based on the form of depiction), because in the essays of this collection can be traced the author's self-presentation. In all the works, the emphasis is made on the authoritative perception of the world, many facts from her life and circumstances of how her artistic and philosophical works were being written are named. Most of them are written from the first person, the transformation in «we» occurs in the interpretation of the global aspects of life. Of course, this is an anthropomorphic narrator: everything is humanized in the text, the artist, the thinker and the observer are main characters in O. Zabuzhko's essays. Essayistic style of $\mathrm{O}$. Zabuzhko is characterized by complex structures, long, complicated sentences with a large number of inserted structures, taken in brackets, separated dashes, abundant foreign-language terminology, citation, interspersion of names, surnames, free retelling of what had been read and contemplated. Her essayist style is close to scientific approach, supplemented by emotional and figurative elements. However, in some cases, the author may deviate from this way of presenting events: markedly in this sense, the work «Read Me», written as a preface to the publication «Alice in the Wonderland» by L. Carol, is distinguished.

According to the place that narrator occupies in the system of a certain story, is to a greater degree the primary narrator, although there are cases of both the secondary and the third-party narrator. The primary narrator is still dominant: the one who travels, thinks, reads, sees, summarizes and shares with the reader the results of what he has seen, comprehended and generalized.

In terms of diegetics (relation to the world), O. Zabuzhko's essayistic «self» should be attributed to the diegetic type, because in the picture of comprehended world, narrator appears in two categories: in the process of narration and comprehension (as a subject), and in included stories (as an object). The difference of this type in essays, for example, from the traditional epic work, is that there he remains outside the framework of the «inner world», and in the essay he enters the inner world of the text itself.

Of course, in separate texts there are possible transitions from implicit to explicit features, as well as from subjective to objective narrator, but the 
general picture, as can be seen from the collection as a conditionally integral entity, looks like this.

According to other characteristics, this type of narrator is strongly revealed, deliberately underlined (by the degree of detection), personal, the figure of «self» is dominant in all works (based on personal qualities) and scattered: despite the fact that from all works there appears to be a single formally identical image of narrator-intellectual, her embodiment is always different, heterogeneous (according to homogeneity), all-knowing (by awareness), ubiquitous (in space), she is a professional philosopher, literary critic, expert in cultural studies, reliable (based on reliability) writer (based on professionalism) [10, 45].

Thus, O. Zabuzhko's book «From the map of books and people» is characterized by a mentative and narrative organization. Narrative is subjected to mentative, in other words, to life stories, events, facts that are retold and give direction to the author's thought, set the vector of reflection, while still remaining a secondary element of text. Mentative's role is dominant. Its main features are: internal dialogue, close connections between thoughts that form the basis of the reference zone, and not events or chronotopes, reflection and meditation as the basis of the text, which defines a variety of communicative strategies of negation, commentary, complementing, interpreting and evaluation. Moreover, O. Zabuzhko's mentative is characterized by emphasized egocentricity, associativity of linguistic activity, intellectualism, special uncompromising rhythm of narration, a complex syntactic organization with quotations, free transfer of other people's ideas, retreats, excursions, complemented by «epilogues», «prologues», and postscripts. Her essays are characterised by fluidity of consciousness in the process of direct understanding of the phenomena of being. Nevertheless, the main components are not events, but their comprehension, not history, but their involvement in opinion, not existence, but its interpretation, not reality, but its creative reconstruction. Therefore, essays, represented, for example, by O. Zabuzhko in the book «From the map of books and people» are based on artistic visualisation of artistic reflexion, meditation, reflection of experiences from a particular mental event, open up new possibilities for the art of word in modern literary process, because in this way, the artist can become closer and more accessible to his reader, discover new facets of creative «self», and this may be the subject of further scientific studies. 


\section{REFERENCES}

1. Arziamova O. V. (2011) «Yazykovye osobennosty mentatyvnoho povestvovanyia s tochky zrenyia lynhvystyky narratyva (na materyale romana A. V. Ylychevskoho «Ai-Petry»)», Vestnyk Rossyiskoho unyversyteta druzhy narodov, issue 1, pp. 21-28. [in Russian].

2. Zabuzhko O. (2012) «Z mapy knyh i liudei : zbirka eseistyky», Meridian Czernowitz, TOV «Drukarnia «Ruta», 376 3. [in Ukrainian].

3. Zatsepyn K. (2010) «Esse: ot fylosofiyi k literature», issue 104, available at: http://magazines. russ.ru/nlo/2010/104/za17.html [in Russian].

4. Zenkyn S. N. (2003) «Krytyka narratyvnoho razuma (Zametky o teoryy, 4)», Novoe lyteraturnoe obozrenye, issue 59, available at: http://magazines.russ.ru/ nlo/2003/59/zen-pr.html [In Russian].

5. Korchynskyi A. V. (2015) «Formanty mysly: Lyteratura u fylosofskyi dyskurs», Yazyky slavianskoi kultury, p. 288 s. [in Russian].

6. Lialiaev S. V. (2010) «Rol mentatyvnykh komponentov v romane B. L. Pasternaka «Doktor Zhyvaho», Novyi fylolohycheskyi vestnyk, issue 1, pp. 111-119. [in Russian].

7. Maksymova N. V. (2012) «Ponymanye v dyalohe: tekstovye modely mentatyva : monohrafyia», 199 p., available at: https://www.metod-kopilka. ru/tekstovaya kultura__modeli_rassuzhdeniya_v_russkom_tekste._monografiya-26564.htm [in Russian].

8. Nosova B. (2015) «Metafora yak okreslennia kulturnoho prostoru intelektuala v eseiakh O. Zabuzhko «Z mapy knyh i liudei», Styl i tekst, issue 15, pp. 136-146. [In Ukrainian].

9. Tiupa V. (2006) «Kommunykatyvnye stratehy teoretycheskoho dyskursa», Krytyka y semyotyka, issue 10, pp. 36-45. [in Russian].

10. Shmyd V. (2003) «Narratolohyia», Yazyky slavianskoi kultury, 312 p. [in Russian].

\section{МЕНТАТИВНО-НАРРАТИВНЫЕ ОСОБЕННОСТИ ЭССЕИСТИКИ О. ЗАБУЖКО}

Тетяна Шевченко, канд. филол. наук, доцент, докторант

Одесский национальный университет имени И. И. Мечникова

В статье идет речь о ментативно-нарративных особенностях эссестики О. Забужко на примере книги «Из карты книг и людей». Очерчено классификацию эссеистики современных украинских писателей по нарративно-ментативной специфике. Сделаны выводы о роли нарративних компонентов в дискурсивной практике эссе, природа которого в целом ментативная. Выделена специфика собственно писательского эссе, который становится платформой возможной «пролонгаиии» собственно художественных произведений прозаиков, ареной их до-интерпретации или ре-интерпретации.

Ключевые слова:ментатив, нарратив, эссеистика, классификация, референция. 


\section{МЕНТАТИВНО-НАРАТИВНІ ОСОБЛИВОСТІ ЕСЕЇСТИКИ О. ЗАБУЖКО}

Тетяна Шевченко, канд. філол. н., доцент, докторант

Одеський національний університет імені I. I. Мечникова

У статті йдеться про ментативно-наративні особливості есеїстики О. Забужко на прикладі книги «З мапи книг і людей». Окреслено класифікацію есеїстики сучасних українських письменників за наративно-ментативною специфікою. Зроблено висновки про роль наративних компонентів у дискурсивній практиці есе, природа якого в цілому ментативна. Виділено специфіку власне письменницького есе, котрий стає платформою можливої «пролонгації» власне художніх творів митців, ареною їх до-інтерпретації чи ре-інтерпретації. Книга О. Забужко «З мапи книг i людей» характеризується ментативно-наративною організацією. Доведено, що у книзі наратив підпорядковується ментативу, іншими словами, історії життя. Подіі, факти, які переповідаються, скеровують авторську думку, спрямовують вектор рефлексії, однак виступають другорядним елементом тексту. Ментатив тут усе-таки першорядний. Його головні прикмети такі: внутрішня діалогізація, тісний зв'язок між думками, які складають основу референтної зони (а не події чи хронотопу), рефлексія і міркування як основа тексту, що визначає різноманітні комунікативні стратегії заперечення, коментування, доповнення, тлумачення, оцінювання. Крім того, ментатив О. Забужкко характеризується підкресленою егоцентричністю, асоціативністю мовомисленнєвої діяльності, інтелектуалізмом, особливим непоспішливим ритмом розповіді, сугестією, складною синтаксичною організацією з цитатами, вільним переказом чужих ідей, відступами, екскурсами, доповненими «епілогами», «прологами», постскриптумами. Ї̈ есеям властива своєрідна плинність свідомості у процесі безпосереднього осмислення явиш буття. Тут усе-таки головне не події, а їх осмислення, не історії, а їх задіяність в опінії, не буття, а його інтерпретація, не дійсність, а їі креативне конструювання. Виходячи з цього, письменницька есеїстика, репрезентована, наприклад, книгою «З мапи книг i людей» О. Забужко, загрунтовується на художньому унаочненні процесів міркування, медитації, відображенні переживань тієї чи іншої ментальної подї̈. Вона відкриває нові можливості мистецтва слова в сучасному літературному процесі, адже в такий спосіб митець може стати ближчим і доступнішим своєму читачеві.

Ключові слова: ментатив, наратив, есеїстика, класифікація, референція.

\section{СПИСОК ВИКОРИСТАНИХ ДЖЕРЕЛ}

1. Арзямова О. В. Языковые особенности ментативного повествования с точки зрения лингвистики нарратива (на материале романа А. В. Иличевского «Ай-Петри») / О.В.Арзямова // Вестник Российского университета дружбы народов. Серия: Русский и иностранный языки и методика их преподавания. -2011 . - № 1. - С. 21-28.

2. Забужко О. 3 мапи книг і людей : збірка есеїстики / О. Забужко // Meridian Czernowitz. - Кам'янець-Подільський, ТОВ «Друкарня «Рута»», 2012. $376 \mathrm{c}$. 
3. Зацепин К. Эссе: от философии к литературе [Электронный ресурс]/ К. Зацепин // НЛО. - 2010. — № 104. - Режим доступа : http://magazines. russ.ru/nlo/2010/104/za17.html

4. Зенкин С. Н. Критика нарративного разума (Заметки о теории, 4) [Электронный ресурс] // Новое литературное обозрение. - 2003. - № 59. Режим доступа : http://magazines.russ.ru/nlo/2003/59/zen-pr.html

5. Корчинский А. В. Форманты мысли: литература и философский дискурс. - М. : Языки славянской культуры, 2015. - 288 с. - (Коммуникативные стратегии культуры).

6. Ляляев С. В. Роль ментативных компонентов в романе Б. Л. Пастернака «Доктор Живаго» / С. В. Ляляев // Новый филологический вестник. 2010. - № 1. - С. 111-119.

7. Максимова Н. В. Понимание в диалоге: текстовые модели ментатива : монография [Электронный ресурс] / Н. В. Максимова ; Новосиб. ин-т повышения квалификации и переподгот. работников образования. Новосибирск : Изд-во НИПКиПРО, 2012. - 199 с. - Режим доступа : https://www.metod-kopilka. ru/tekstovaya_kultura_modeli_rassuzhdeniya_v_ russkom_tekste._monografiya-26564.htm.

8. Носова Б. Метафора як окреслення культурного простору інтелектуала в есеях О. Забужко «3 мапи книг і людей» / Б. Носова // Стиль і текст. 2015. - № 15. - С. 136-146.

9. Тюпа В. Коммуникативные стратеги теоретического дискурса / В. Тюпа // Критика и семиотика. - 2006. - Вып. 10. - С. 36-45.

10. Шмид В. Нарратология / В. Шмид. - М. : Языки славянской культуры, 2003. $-312 \mathrm{c}$. 